\title{
Rapidly progressive non-arteritic anterior ischaemic optic neuropathy
}

\author{
Safwan Tayeb, ${ }^{1}$ Amir Vosoughi, ${ }^{2}$ Jonathan A Micieli (1) ${ }^{1}$
}

${ }^{1}$ Department of Ophthalmology and Vision Sciences, University of Toronto, Toronto, Ontario, Canada

${ }^{2}$ Faculty of Medicine, University of Manitoba, Winnipeg, Ontario, Canada

\section{Correspondence to} Dr Jonathan A Micieli; jonathanmicieli@gmail.com

Accepted 9 November 2021

\section{DESCRIPTION}

Non-arteritic anterior ischaemic optic neuropathy (NAION) typically presents with sudden painless vision loss in those with vascular risk factors and a 'disc-at-risk'. ${ }^{1}$ Following the initial insult, most patients remain stable or may notice slight improvement in their vision. However, a minority of patients suffer from a progressive form of NAION and their vision deteriorates further after the initial examination. ${ }^{23}$ Here, we provide the striking image of one such rapid case.

A 55-year-old man was referred to neuroophthalmology for right eye vision loss. He had a history of hypertrophic cardiomyopathy, dyslipidaemia and left NAION 16 years prior. His medications included rosuvastatin and bisoprolol and he smoked half pack of cigarettes per day for 30 years. He reported right eye painless vision loss 4 days prior to presentation and was found to have a visual acuity of 20/20 right eye (OD) and 20/60 left eye (OS) and Humphrey 24-2 SITA-Fast visual fields showed bilateral inferior altitudinal defects (figure 1). Dilated fundus examination showed superior greater than inferior optic disc oedema with superior haemorrhages OD and left superior segmentation optic disc pallor (figure 1). $\mathrm{He}$ was diagnosed with acute right NAION and complete blood count, erythrocyte sedimentation rate and $\mathrm{C}$ reactive protein were normal. Three days later, he noticed worsening of his right eye vision that involved the superior part of his right visual field. He was re-examined and found to have a visual acuity of counting fingers at one foot OD and 20/60 OS. There was a right relative afferent pupillary defect (RAPD) and Humphrey 24-2 SITAFast visual fields in the right eye showed severe
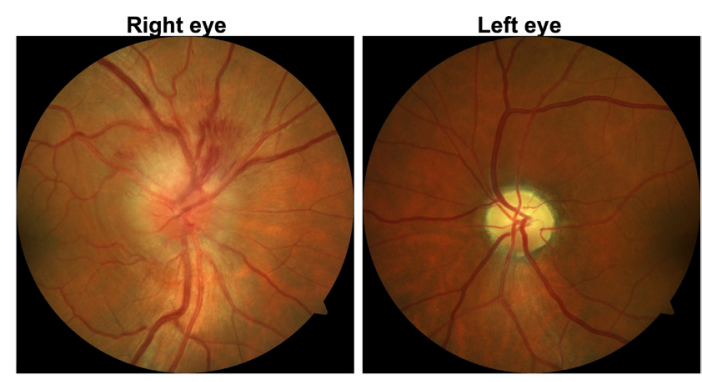

Limited 2021. No commercia re-use. See rights and permissions. Published by BMJ.

To cite: Tayeb S, Vosoughi A, Micieli JA. BMJ Case Rep 2021;14:e247167. doi:10.1136/bcr-2021247167

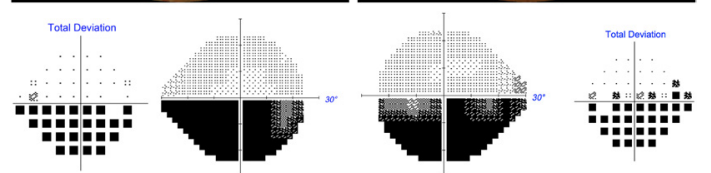

Figure 1 Optic disc photos and Humphrey 24-2 SITAFast visual fields at presentation.

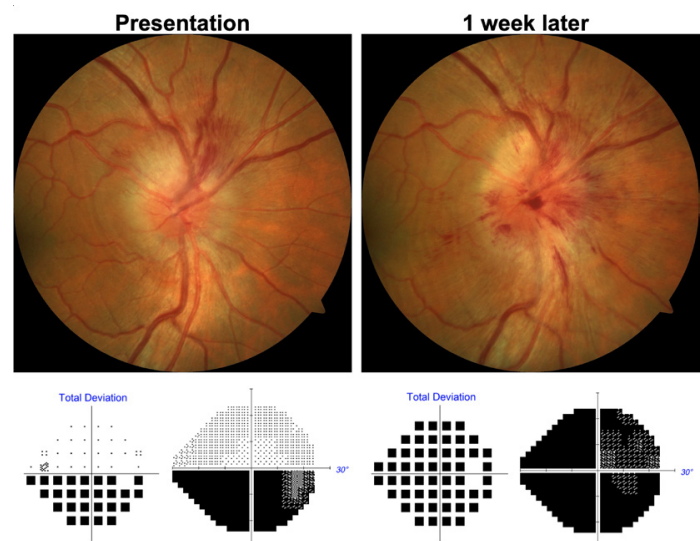

Figure 2 Rapid progression of non-arteritic anterior ischaemic optic neuropathy with worsening of optic disc oedema and visual fields deficits over 1 week.

generalised depression (figure 2). Dilated fundus examination showed new inferior haemorrhagic optic disc oedema, worse compared with his initial presentation (figure 2).

Progressive visual loss in NAION is uncommon and should be differentiated from recurrence, which indicates NAION redevelops after the initial optic disc oedema resolves. Progression was previously defined by Arnold et al as worsening of visual acuity by at least three lines or at least $3.0 \mathrm{~dB}$ on quantitative perimetry during the first 30 days after initial vision loss and has been reported to occur in the range of $22 \%-37 \% .^{4}$ A number of smaller case series have described cases in more detail such as Borchert and Lessell who described a series of eight patients that had progression of NAION over weeks to months. ${ }^{5}$ Beck et al documented three cases that progressed between 1 and 3 weeks after onset. ${ }^{6}$ Our case stands out as the progression occurred rapidly within 1 week of initial symptom onset and the progression took his entire visual field after an initial inferior altitudinal defect. The presence of optic disc oedema creates more crowding at the optic nerve head and the swollen axons may further compromise blood flow providing an explanation for this occurrence. ${ }^{78}$ Unfortunately, there is no established treatment for $\mathrm{NAION}^{9}$ and there was no evidence the optic nerve decompression was helpful even in those with progressive NAION. ${ }^{2}$ Although NAION is typically thought of as a non-progressive disease, this case demonstrates that it can progress when the optic disc remains oedematous.

Contributors JM and ST identified and managed the case, and had the idea for the case. All authors were involved in performing a literature search and writing the article. 


\section{Learning points}

- Non-arteritic anterior ischaemic optic neuropathy is typically a non-progressive disease. However, progression is possible in the first 6-8 weeks when the optic nerve is still oedematous.

- Segmental optic disc oedema is a characteristic finding in non-arteritic anterior ischaemic optic neuropathy. Early progression is typically associated with worsening optic disc oedema in the area of the optic nerve that was relatively spared initially.

Funding The authors have not declared a specific grant for this research from any funding agency in the public, commercial or not-for-profit sectors.

Competing interests None declared.

Patient consent for publication Consent obtained directly from patient(s).

Provenance and peer review Not commissioned; externally peer reviewed.

Case reports provide a valuable learning resource for the scientific community and can indicate areas of interest for future research. They should not be used in isolation to guide treatment choices or public health policy.

\section{ORCID iD}

Jonathan A Micieli http://orcid.org/0000-0003-4911-9152

\section{REFERENCES}

1 Miller NR, Arnold AC. Current concepts in the diagnosis, pathogenesis and management of nonarteritic anterior ischaemic optic neuropathy. Eye 2015;29:65-79.

2 Newman NJ. The ischemic optic neuropathy decompression trial. Arch Ophthalmol 2007; 125:1568-70

3 Hayreh SS, Zimmerman MB. Nonarteritic anterior ischemic optic neuropathy: natural history of visual outcome. Ophthalmology 2008;115:298-305.

4 Arnold AC, Costa RMS, Dumitrascu OM. The spectrum of optic disc ischemia in patients younger than 50 years (an Amercian Ophthalmological Society thesis). Trans Am Ophthalmol Soc 2013;111:93-118.

5 Borchert M, Lessell S. Progressive and recurrent nonarteritic anterior ischemic optic neuropathy. Am J Ophthalmol 1988;106:443-9.

6 Beck RW, Savino PJ, Schatz NJ, et al. Anterior ischaemic optic neuropathy: recurrent episodes in the same eye. Br J Ophthalmol 1983;67:705-9.

7 Biousse V, Newman NJ. Ischemic optic neuropathies. N Engl J Med 2015;372:2428-36.

8 Hayreh SS. Ischemic optic neuropathy. Prog Retin Eye Res 2009;28:34-62.

9 Salomon 0, Huna-Baron R, Steinberg DM, et al. Role of aspirin in reducing the frequency of second eye involvement in patients with non-arteritic anterior ischaemic optic neuropathy. Eye 1999;13 (Pt 3a):357-9.

Copyright 2021 BMJ Publishing Group. All rights reserved. For permission to reuse any of this content visit

https://www.bmj.com/company/products-services/rights-and-licensing/permissions/

BMJ Case Report Fellows may re-use this article for personal use and teaching without any further permission.

Become a Fellow of BMJ Case Reports today and you can:

- Submit as many cases as you like

Enjoy fast sympathetic peer review and rapid publication of accepted articles

- Access all the published articles

- Re-use any of the published material for personal use and teaching without further permission

\section{Customer Service}

If you have any further queries about your subscription, please contact our customer services team on +44 (0) 2071111105 or via email at support@bmj.com.

Visit casereports.bmj.com for more articles like this and to become a Fellow 